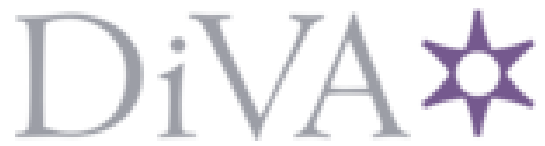

http://www.diva-portal.org

\title{
Postprint
}

This is the accepted version of a paper published in . This paper has been peer-reviewed but does not include the final publisher proof-corrections or journal pagination.

Citation for the original published paper (version of record):

Olson, J. (2018)

Review of Richard Joyce, Essays in Moral Skepticism

International Journal for the Study of Skepticism, 8(1): 66-71

https://doi.org/10.1163/22105700-20171273

Access to the published version may require subscription.

N.B. When citing this work, cite the original published paper.

Permanent link to this version:

http://urn.kb.se/resolve?urn=urn:nbn:se:su:diva-153735 


\section{Richard Joyce}

Essays in Moral Skepticism. Oxford: Oxford University Press, 2016.

Pp. 274. ISBN 978-0-19-875487-9

Since the beginning of the millennium, Richard Joyce has made several influential contributions to contemporary metaethics. He has revived moral error theory, championed evolutionary debunking arguments, and developed and defended a position known as 'moral fictionalism'. The twelve papers in this volume are organized around these themes - error theory, evolution and debunking, and projectivism and fictionalism—with four papers in each of the three categories. All papers but one are previously published. I had read nearly all of them before and I have used many of them in my own work. Needless to say, then, I think highly of Joyce's work and I benefited from engaging with the material anew. The volume also contains a newly written introductory chapter, which I found helpful.

Some readers may be surprised and perhaps disappointed to discover that despite the title of Part 1 ('Error Theory'), it is difficult to find any positive arguments in favour of error theory. Joyce's primary concern is not to defend error theory, but rather to clarify and explore the view, and to consider questions that arise in connection with it. The same kind of probing approach permeates the chapters in Parts 2 and 3. Joyce is generally more concerned to explore the views he engages with, rather than outright defending them. Readers might find themselves requesting more distinctive arguments but whatever disappointment this invites need not last long, for Joyce's exploratory discussions are always interesting, instructive, and useful, and sometimes ingenious. (An editorial shortcoming that will cause annoyance among readers is that cross-references are to the original publications and not to the papers as they appear in the volume.) 
One interesting point that emerges already in the introduction (p. 3) is that the view Joyce favours is not a traditional form of error theory, but a kind of combination of error theoretic cognitivism and non-cognitivism. The view is developed in the volume's first chapter, 'Expressivism, Motivation, Internalism, and Hume', in which Joyce also tentatively interprets Hume as holding a metaethical view along these lines. On this hybrid view, the judgement that Hitler was evil expresses the belief or proposition that Hitler had the non-existent or noninstantiated property of being evil (hence the view is error theoretic), and the conative attitude of subscribing to a normative standard that condemns Hitler's actions (p. 29).

This hybrid view is an interesting suggestion, but I doubt that Joyce has chosen a compelling way of illustrating it. As far as I understand, the main argument in favour of the view that the meaning of moral judgements is partly non-cognitive is that it would be odd or incoherent to utter sentences like the following: 'Hitler was evil. But I subscribe to no normative standard that condemns his actions.' (p. 32-3) I agree that it would sound odd to judge that Hitler was evil and go on to report that one subscribes to no normative standard that condemns his actions, but this could be because it is natural to take subscription to a normative standard to be a cognitive act, e.g., that of believing that the standard in question is correct. If it is assumed that subscription to a normative standard is a conative attitude it is far from clear that it would be incoherent to judge, e.g., that Hitler was evil and go on to report that one subscribes to no normative standard that condemns his actions. We certainly expect speakers' conative attitudes to match their moral judgements, but this gives little or no support to the hybrid view that 'moral judgments express, as a matter of entrenched linguistic convention, both beliefs and conative attitudes' (p. 34, first emphasis added).

The remaining three chapters in Part 1 discuss questions that arise in connection with error theory, such as the relation between moral error theory and self-interest and ways in which defenders of various metaethical positions may end up unwittingly defending error theories, 
thereby becoming 'accidental' error theorists. Joyce also devotes a paper to en exploration of 'metaethical pluralism', and in particular of the view that moral judgement and related concepts are too indeterminate for there to be a fact of the matter as to whether moral naturalism or moral scepticism (either error theory or non-cognitivism) is true. Joyce takes this possibility to imply that both positions may be permissible (p. 104). As I have argued elsewhere, however, if it is undecidable whether moral naturalism or moral scepticism is true, it is difficult to see how and why both positions could be (epistemically) permissible; if there is no fact of the matter and if there is sufficient evidence that this is so, then it seems that that would be the only (epistemically) permissible metaethical position to take (Johansson \& Olson 2015: 603-4).

The first two chapters in Part 2 ('Evolution and Debunking') are less concerned with metaethics proper than the rest of the volume. Here Joyce takes issue with nativist and antinativist accounts of moral judgement. The aforementioned indeterminacies of moral judgement and related concepts resurface in these discussions and, according to Joyce, make it difficult to determine the issue between nativist and anti-nativist views. As before, Joyce's primary aim is not to offer decisive arguments, but to explore and clarify what it would mean for the capacity of moral judgement to be either an adaptation or a by-product ('spandrel') of natural selection. Both chapters are illuminating and helpful contributions, especially for metaethicists who are not up to date on the philosophy of biology.

The remaining two chapters in Part 2 examine the metaethical relevance of genealogical debunking arguments in ethics, in particular evolutionary debunking arguments ('EDAs'). One general message of Joyce's judicious discussions is that while EDAs are congenial to moral error theory and to the sceptical view that moral judgements lack epistemic justification, they do not suffice to establish either of these views on their own. An EDA may be used to shift the burden of proof onto the realist or non-sceptic, or be combined with some 
other consideration, such as a principle of parsimony, in order to make a case for moral error theory or moral scepticism (p. 174). I agree with Joyce that the metaethical implications of EDAs and other debunking arguments are limited. Such arguments can serve defensive purposes for moral error theorists and sceptics, insofar as they provide plausible responses to realists' and non-sceptics' demands for explanations of why we tend to make moral judgements, sometimes with great confidence, although they are uniformly false or untrue, or uniformly unjustified (Olson 2014: 139-48).

While Joyce stresses the limited metaethical implications of EDAs, he is at the same time unimpressed by recent responses to this kind of argument. He goes as far as to say that 'not one of [the] debunkers of debunking has made a serious effort' to find a place for moral facts in the evolutionary genealogy of moral judgement (p. 155). I am not sure that this is a fair complaint. Many moral realists hold that moral facts are explanatory only within the moral domain; moral facts can only explain other moral facts. Therefore, we should not expect moral facts to have a place in the explanation of our capacity of moral judgement or of our moral beliefs. The realist and non-sceptic might accept something like Joyce's genealogical account (his EDA), but insist that this does not show that our moral beliefs cannot be justified. It is a natural and familiar suggestion that we can justify our moral beliefs by the same kind of process that we justify many other philosophical beliefs, i.e., via a priori reflection, and by systematic normative theorizing. It is of course arguable that a priori reflection and normative theorizing do not in the end engender normative knowledge, either because they ultimately fail to provide epistemic justification or because there are no moral truths. But making the case for either of these claims takes us beyond the EDAs and (back) into familiar metaethical and epistemological territories.

This again illustrates that EDAs do not on their own establish anti-realist or sceptical conclusions, which is a general point that Joyce endorses, as we have seen. Instead, he prefers 
to say that EDAs shift the burden of proof onto the moral realists and non-sceptics (e.g., pp. $155-8,161,174)$. But I am not sure why the burden cannot be shouldered in roughly the way sketched in the previous paragraph. If debunkers want to argue that the burden is so heavy as to make realism and non-scepticism crumble, they would, again, have to go beyond EDAs and (back) into familiar metaethical territory.

The first two chapters in Part 3 ('Projectivism and Fictionalism') are brilliant expositions of doctrines and ideas that appear frequently in the literature on metaethics, often without sufficient precision. In 'Patterns of Objectification', Joyce seeks to precisify Mackie's notion of objectification and what role it plays in Mackie's argument for moral error theory. 'Is Moral Projectivism Empirically Tractable?' develops a similar theme. Here Joyce seeks to substantiate the metaphorical idea that moral judgements are the upshots of projected attitudes, which leads him to distinguish between a number of theses that all deserve to go by the name 'moral projectivism'. The discussion is formidably illuminating and especially welcome, since 'projectivism' has been used, rather confusingly, as a label for such diverse metaethical theories as error theory and non-cognitivism. Joyce argues persuasively that what he calls 'minimal projectivism' (pp. 200-18), which comprises a phenomenological and a psychological thesis about moral judgement, does not imply scepticism and is neutral between cognitivism and non-cognitivism, and realism and anti-realism. He also argues that his precisifications render minimal moral projectivism a hypothesis that is, at least in principle, empirically testable (p. 203).

The penultimate chapter in the volume is an elaboration and defence of moral fictionalism. The background question here is what to do with moral thought and discourse if some form of moral error theory is accepted. It might be thought that the natural move to make for someone who holds that moral judgements are uniformly false or untrue is to abolish moral thought and discourse. However, abolitionism is far from the only option for moral error theorists. Nor is 
it clearly a desirable option. One reason is that moral judgements are practically useful in that they work 'as a bulwark against weakness of will' (p. 232). Fictionalists like Joyce hold that we can continue to reap the benefits of this feature of moral judgement, without committing to massive error, if we take up a propositional attitude of make-belief, rather than belief, toward moral propositions, and if we utter moral sentences without assertoric force.

In Joyce's view, once moral error theory has been accepted, it is not an attractive option to carry on as before and (try) to maintain erroneous moral belief and make false moral judgements, at least not for a community of speakers (p. 229). In my view, however, Joyce has not done enough to make this point convincing, and in some of my previous work I have argued that he has not made a strong enough case for why moral fictionalism is preferable to what I have called 'moral conservationism' (Olson 2014: Ch. 9). I will not repeat my criticisms here, however. In any case, Joyce's chapter on moral fictionalism is an important contribution that, along with the final chapter of his book The Myth of Morality (2001), has sparked a lively debate that still goes on.

In the volume's final chapter, Joyce expands fictionalism to the domain of the psychological, yielding a view called 'psychological fictionalism'. The background assumption here is that we endorse a view like the Churchlands' eliminativism, according to which folk psychology is systematically in error; there is nothing in reality that correspond to folk psychological terms like 'belief' and 'desire'. The hypothesis that Joyce examines sympathetically is that we can continue to reap the benefits of folk psychological thought and discourse (whatever they are exactly) if we become fictionalists about belief and desire, and other such states (p. 246-7).

Unlike its analogue moral fictionalism, psychological fictionalism faces a thorny problem, which Joyce calls 'fictionalist suicide' (p. 251). Remember that the background assumption of Joyce's revolutionary psychological fictionalism is that we endorse eliminativism about folk 
psychological states, such as belief and desire. Remember also that the psychological fictionalist recommends that we take up an attitude of make-belief toward propositions concerning folk psychological states. The problem is that the attitude of make-belief appears to be among the folk psychological states that do not exist, according to eliminativism. Joyce's favoured solution is the following: 'Instead of recommending that we make-believe rather than believe propositions of the form "Mary believes that $p$ ", the fictionalist recommends that we adopt brain state $\mathrm{M}$ rather than brain state B toward such propositions.' (p. 254)

But why recommend that we adopt brain state $\mathrm{M}$ rather than brain state $\mathrm{B}$ toward propositions of the relevant kind? The initially tempting explanation is that brain state $\mathrm{M}$ correlates with, or realizes, the attitude of make-belief. But the fictionalist who is also an eliminativist about folk psychological states is obviously not in a position to offer that kind of explanation. It seems that rather than solving the problem for psychological fictionalism, Joyce offers another theory, for which the problem does not arise. The problem does not arise for this alternative theory because it involves no recommendation of make-belief. But it is difficult to see in what sense a theory that recommends adopting certain brain states rather than others is a version of fictionalism. For this reason, it is difficult not to conclude that the threat of fictionalist suicide still looms large.

As I have already stressed, there is a lot to learn from this volume. Joyce writes with great clarity and his judicious treatment of complex philosophical issues is highly commendable. It is a terrific asset for both students and researchers working on metaethics to have his most influential papers collected in one volume. ${ }^{1}$

\section{References}

\footnotetext{
${ }^{1}$ Thanks to Victor Moberger for helpful comments on an earlier draft of this review. A generous grant from Riksbankens Jubileumsfond is gratefully acknowledged (grant no 1432305).
} 
Johansson, J. and J. Olson 2015. 'Against Pluralism in Metaethics', in C. Daly (ed.), The Palgrave Handbook of Philosophical Methods. Basingstoke: Palgrave Macmillan, 593609.

Joyce, R. 2001. The Myth of Morality. Cambridge: Cambridge University Press.

Olson, J. 2014. Moral Error Theory: History, Critique, Defence. Oxford: Oxford University Press. 